\title{
Piquetes como repertório: organização operária e redes sociais nas greves de 1957 e $1980^{*}$
}

\author{
Paulo Fontes** \\ Francisco Macedo***
}

\section{RESUMO}

Este artigo analisa o papel dos piquetes em duas das mais importantes greves da história brasileira, a "greve dos 400 mil", que envolveu diversas categorias industriais em São Paulo e cidades vizinhas em 1957, e a "greve dos 41 dias", em 1980, organizada pelos metalúrgicos do ABC Paulista, na regiáo metropolitana da cidade de São Paulo. Embora separadas no tempo em quase 25 anos, essas duas grandes paralisaçóes se tornaram exemplos paradigmáticos das formas de ação sindical, tanto do sindicalismo sustentado pelo bloco formado pelas forças "nacional-reformistas" e comunistas, hegemônicas no período anterior ao golpe civil-militar de 1964, quanto do "novo sindicalismo" que emergiu a partir do final dos anos 1970. A análise mais detida das greves mostra elementos destacados de aproximação e semelhanças entre os dois movimentos. A análise mais apurada da ação dos piquetes indica um repertório organizativo mais permanente e resistente do que indicado pela bibliografia especializada e pelo discurso das lideranças políticas e sindicais.

Palavras-chave: greves; piquetes; trabalhadores; sindicalismo.

\section{ABSTRACT}

This article analyzes the role of pickets in two of the most emblematic strikes in Brazilian labor history: the "strike of the 400,000," which involved several industry sectors in São Paulo and neighboring cities in 1957, and the 1980 "forty-one days strike," involving the metalworkers of the ABC Paulista, in the metropolitan area of the city of São Paulo. Both strikes broke out at a time of profound reconfiguration of Brazilian society, marked by the processes of industrialization, migration, and urbanization. Although separated by a time

DOI - http://dx.doi.org/10.1590/2237-101X0183402

Artigo recebido em 4 de maio de 2016 e aprovado para publicação em 5 de dezembro de 2016.

* Uma versão preliminar e modificada deste artigo foi publicada em inglês na revista International Labor and Working-Class History vol. 83, Spring 2013.

** Professor na Escola de Ciências Sociais da Fundação Getulio Vargas (CPDOC/FGV), Rio de Janeiro - RJ, Brasil e pesquisador bolsista produtividade do CNPq. E-mail: paulo.fontes@fgv.br.

*** Professor no Instituto Federal de Educação, Ciência e Tecnologia de Minas Gerais. Belo Horizonte, MG, Brasil. E-mail: francisco.macedo@ifmg.edu.br. 
gap of almost twenty-five years, both the "strike of the 400,000" and the "forty-one days strike" reveal important aspects of continuities in the performances and the organizational repertoires of the workers in São Paulo.

Keywords: Strikes; Pickets; Workers, Trade Unions.

\section{RESUMEN}

Este artículo analiza el rol de los piquetes en dos de las más importantes huelgas de la história brasileña, la "huelga de los 400 mil", de varios sectores industriales de São Paulo y ciudades vecinas en 1957, y la "huelga de los 41 días", en 1980, organizada por los metalúrgicos del ABC Paulista, en región metropolitana de la ciudad de São Paulo. Aunque separadas en el tiempo por casi 25 años, las dos huelgas se convierteron en ejemplos paradigmáticos de las formas de acción sindical adoptadas, de un lado, por el sindicalismo del bloque formado por las fuerzas "nacional-reformistas" y comunistas, hegemónicas en el periodo anterior al golpe civil-militar de 1964, y, de otro lado, también por el "nuevo sindicalismo" que emergió en fines de los 1970. El análisis más detallado de las huelgas revela elementos resaltados de aproximación y semejanzas entre los dos movimientos. El análisis más preciso de la acción de los piquetes indica un repertorio organizativo más permanente y resistente que el indicado por la bibliografía especializada y por el discurso de los liderazgos políticos y sindicales.

Palabras clave: huelgas; piquetes; trabajadores; sindicalismo.

Neste artigo analisamos o papel dos piquetes em duas das mais emblemáticas greves da história brasileira, a "greve dos 400 mil", que envolveu diversas categorias industriais em São Paulo e cidades vizinhas em 1957, e a "greve dos 41 dias", em 1980, organizada pelos metalúrgicos do ABC Paulista na regiáo metropolitana da cidade de São Paulo. Embora separadas no tempo em quase 25 anos, essas duas grandes paralisaçôes se tornaram exemplos paradigmáticos das formas de ação sindical, tanto do sindicalismo sustentado pelo bloco formado pelas forças "nacional-reformistas" e comunistas, hegemônicas no período anterior ao golpe civil-militar de 1964, quanto do "novo sindicalismo" que emergiu a partir do final dos anos 1970, e que se organizou em torno do Partido dos Trabalhadores (PT) e da Central Única dos Trabalhadores (CUT).

Apesar da distância cronológica e das diferenças políticas, a análise mais detida das greves mostra elementos destacados de aproximação e semelhanças entre os dois movimentos. A ação dos piquetes, em particular, mas também a organização dos trabalhadores no local de trabalho e nos bairros operários, bem como os rituais e performances dos grevistas são exemplos de algumas dessas analogias, indicando um repertório organizativo mais permanente e resistente do que indicado pela bibliografia especializada e pelo discurso das lideranças políticas e sindicais. 
Durante anos, boa parte da literatura sobre sindicalismo no Brasil foi marcada pelo peso do golpe de 1964, que também teria representado uma clivagem fundamental na trajetória do movimento operário. A emergência do chamado "novo sindicalismo" e suas impressionantes açôes de massa no final dos anos 1970 teriam acentuado ainda mais a ideia de uma suposta "ruptura" e as descontinuidades entre o movimento sindical pré e pós-regime militar. Desta forma, o sindicalismo anterior a 1964 foi fortemente caracterizado, em grande parte da narrativa acadêmica e sindical, como "velho", "populista", dependente do Estado e pouco organizado nas bases, sendo atuante apenas nos setores tradicionais da economia e frágil nas áreas mais modernas e avançadas.

Esta caracterização que radicalmente opunha um "novo" a um "velho" sindicalismo tem sido questionada e, em grande medida, foi desmontada por vários autores a partir do final dos anos $1990 .{ }^{1}$ Ainda há, no entanto, um longo caminho a percorrer e muita pesquisa a ser feita para, levando-se obviamente em conta as importantes diferenças políticas, econômicas e sociais, analisar as continuidades e descontinuidades nas práticas sindicais e formas organizativas dos trabalhadores nesses dois períodos.

A tradição dominante dos estudos sobre greves na literatura sobre o trabalho no Brasil concentrou-se na análise monográfica de paralisaçóes específicas ou em períodos de tempo relativamente curto se considerados historicamente homogêneos. Há poucas análises comparativas entre greves e ainda são raros os estudos sobre processos grevistas numa longa duração. ${ }^{2}$ Recentes estudos sobre o papel da Justiça do Trabalho nos conflitos trabalhistas têm apontado pistas interessantes para o entendimento dos processos de negociaçóes das greves, inclusive em uma perspectiva de mais largo prazo. ${ }^{3}$ Além disso, ainda sabemos pouco sobre as permanências ou mudanças nos processos de organizaçáo e mobilizaçáo para as paralisaçóes, bem como sobre a geografia das greves, sua dinâmica espacial e suas relaçôes com os processos de industrialização, urbanização e ocupação do espaço público. Estudos diacrônicos, comparativos e densos de movimentos grevistas podem ser, como veremos, reveladores de práticas continuadas surpreendentes na cultura operária, mesmo separadas no tempo e por conjunturas tão diferentes.

\section{A “greve dos 400 mil”, São Paulo, 1957}

Um dos mais famosos e importantes movimentos dos trabalhadores no período que antecedeu o golpe de 1964, a greve de outubro de 1957, ou "greve dos 400 mil", como ficou

\footnotetext{
${ }^{1}$ Cf., entre outros, FORTES, Alexandre et al. Na luta por direitos. Estudos recentes em história social do trabalho. Campinas: Editora da Unicamp, 1999; MATTOS, Marcelo Badaró. Novos e velhos sindicalismos. Rio de Janeiro (1955-1988). Rio de Janeiro: Vício de Leitura, 1998 e SANTANA, Marco Aurélio. Homens partidos: comunistas e sindicatos no Brasil. São Paulo: Boitempo, 2001.

${ }^{2}$ Exceçóes são as análises de alguns sociólogos do trabalho. Cf. Sandoval, 1994 e Noronha, 2009.

${ }^{3}$ Cf. CORRÊA, Larissa Rosa. A tessitura dos direitos. Patrôes e empregados na Justiça do trabalho, 19531964. Sáo Paulo: LTR, 2011 e VARUSSA, Rinaldo. Trabalhadores e a construção da Justiça do Trabalho no Brasil (décadas de 1940 a 1960). São Paulo: LTR, 2012.
} 
conhecida, envolveu diversas categorias industriais em São Paulo e outras regiôes vizinhas. Durante muito tempo, esta greve foi considerada por grande parte dos estudiosos do movimento operário como uma paralisação emblemática de um suposto sindicalismo "populista", frágil em sua organização nas bases, excessivamente atrelado aos interesses políticos dominantes e às instituiçóes estatais. ${ }^{4}$ Estudos mais recentes, no entanto, vêm alterando radicalmente essa avaliação da paralisação e têm revelado um movimento com conexôes muito mais complexas e dinâmicas entre bases operárias, dirigentes sindicais e lideranças políticas. ${ }^{5}$ De toda forma, nas variadas interpretaçóes, o destacado papel desempenhado pelos piquetes durante a "greve dos 400 mil" é um dos pontos centrais das diversas análises.

O protesto operário ocorreu num momento bastante particular. Motivado pelas políticas desenvolvimentistas do governo Juscelino Kubitschek (1956-1961), o país passava por intensas transformaçóes econômicas e sociais que compunham um cenário que favorecia fortemente o otimismo do discurso oficial. Para muitos, parecia próximo o prometido futuro do "país do futuro", aposto que já acompanhava o país por várias geraçôes.

A regiáo metropolitana de Sáo Paulo era uma das mais afetadas por este contraditório processo. Foi ali que a maior parte dos novos e modernos setores industriais se instalou. Impulsionados por uma intensa migração de trabalhadores rurais, a cidade e o cordáo fabril composto pelos municípios adjacentes cresciam num ritmo sem precedentes. Entretanto, se a oferta de empregos aumentava, o mesmo não necessariamente ocorria com os salários. De fato, a mudança da base industrial e tecnológica também implicava a crise de vários setores tradicionais, como a indústria têxtil, uma conhecida empregadora de mulheres. A grande oferta de mão de obra contribuía para a compressão relativa dos salários, apesar do visível desenvolvimento. Além disso, era geral a queixa com o incremento do ritmo de trabalho, provocando estresse, acidentes e uma clara percepção de superexploração. O intenso crescimento de São Paulo apoiava-se numa forte segregaçáo social na cidade. Cada vez mais as classes médias e altas viviam nos bairros mais centrais e bem equipados, enquanto os pobres em geral eram deslocados para a vasta periferia. A especulaçáo imobiliária, a escassez de transporte e a infraestrutura urbana precária definitivamente passavam a ser experiências comuns para a grande maioria da população trabalhadora paulistana. ${ }^{6}$

\footnotetext{
${ }^{4}$ Ver RODRIGUES, Leôncio Martins. Conflito industrial e sindicalismo no Brasil. Sáo Paulo: Difel, 1966; MUNHOZ, Fabio. Sindicalismo e democracia populista: a greve de 1957. São Paulo: Cedec, 1977 e LEITE, Márcia de Paula Leite. Trabalhadores, sindicatos e partidos: a greve de 1957 em São Paulo. In: El sindicalismo latino americano en los ochenta. Santiago del Chile: Clasco, 1985.

${ }^{5}$ FONTES, Paulo. The strike of 400,000 and the workers' organization in São Paulo, Brazil, 1957. Socialist History Journal, Londres, v. 17, p. 61-75, 2000; NEGRO, Antonio Luigi. Linhas de montagem. O industrialismo nacional-desenvolvimentista e a sindicalização dos trabalhadores. São Paulo: Boitempo, 2004; NETO, Murilo Leal Pereira. A reinvenção da classe trabalhadora (1953-1964). Campinas: Editora da Unicamp, 2011 e CORRÊA, Larissa Rosa. A tessitura dos direitos. Patrôes e empregados na Justiça do trabalho, 1953-1964, op. cit.

${ }^{6}$ Para uma análise específica da industrialização em São Paulo e seus efeitos sobre o mercado de trabalho neste período ver COLISTETE, Renato. Labour Relations and Industrial Performance in Brazil. Greater São
} 
Mas no final dos anos 1950 era o custo de vida, acima de tudo, a maior insatisfação dos trabalhadores. Os efeitos inflacionários da política econômica do governo e seu impacto sobre os salários eram reconhecidos pelos próprios industriais e até por instituiçôes como o FMI. Os meses que antecederam a greve foram de intensa agitação nos meios operários de São Paulo. O sindicalismo vivia um momento de visível entusiasmo e reorganização. A greve generalizada dos trabalhadores têxteis, metalúrgicos e outras categorias profissionais em 1953, organizada em grande medida pelas próprias bases operárias, tinha dado um novo impulso para os setores mais aguerridos do movimento. ${ }^{7}$ Somava-se a isso a relativa liberalização das restriçôes à militância sindical levada a cabo no segundo governo de Getúlio Vargas (1951-1954) e que teve continuidade durante o mandato de Kubitschek, o que dava mais liberdade para as açôes dos ativistas, ao menos nos sindicatos, já que nos locais de trabalho, a ação conjunta da famigerada polícia política e social, o DOPS, e grande parte dos empresários e gerentes, mantinha o despotismo fabril em níveis ditatoriais.

Assim, o movimento sindical ganhava espaço na vida pública. Logo após a greve de 1953, foi criado o Pacto de Unidade Intersindical (PUI), reunindo a maioria do sindicalismo mais combativo do período. Consolidava-se uma aliança entre os dirigentes sindicais ligados ao Partido Comunista do Brasil (PCB) e sindicalistas ligados ao Partido Trabalhista Brasileiro (PTB). Porém, não era desprezível a presença de lideranças não ligadas a esses partidos ou próximas a outros políticos, como no caso do então governador de São Paulo, Jânio Quadros. Para além da defesa dos interesses dos trabalhadores, eram o nacionalismo e o anti-imperialismo os discursos que cimentavam tão amplas alianças no interior do movimento sindical.

Foi neste contexto que, em reuniáo convocada pelo PUI no dia 3 de outubro de 1957, os sindicatos paulistanos dos trabalhadores têxteis, metalúrgicos, gráficos, dos mestres e contramestres da indústria de fiação e tecelagem, trabalhadores em curtumes e papeleiros, entre outros, decidiram juntar forças e exigir um aumento salarial de $45 \%$, além de medidas concretas de controle de preços e combate à carestia.

Divididos, os empregadores recusavam-se a negociar, o que ampliava ainda mais insatisfação entre sindicalistas e trabalhadores. Assembleias, passeatas e reuniôes em fábricas e bairros eram convocadas, gerando um clima de crescente mobilização que culminou com a deflagra-

Paulo, 1945-60. Houndmills: Palgrave, 2001 e WEINSTEIN, Barbara. (Re) formação da classe trabalhadora no Brasil (1920-1964). São Paulo: Cortez, 2000. Sobre o processo de segregaçáo social no espaço urbano da cidade ver KOWARICK, Lucio (Org.). As lutas sociais e a cidade: Sáo Paulo: passado e presente. Rio de Janeiro: Paz e Terra, 1988.

${ }^{7}$ Para diferentes abordagens sobre a greve dos 300 mil, ver MOISÉS, José Álvaro. Greve de massa e crise política (estudo da Greve dos 300 mil em São Paulo, 1953-54). São Paulo: Polis, 1978; COSTA, Hélio. Em busca da memória. Comissão de fábrica, partido e sindicato no pós-guerra. São Paulo: Scritta, 1995; WOLFE, Joel. Working women, working men — São Paulo and the rise of Brazil's industrial working class, 1900-1955. Durham: Duke University Press, 1993 e NETO, Murilo Leal Pereira. A reinvenção da classe trabalhadora (1953-1964), op. cit. 
ção da greve em 15 de outubro. Desde as primeiras horas daquele dia, a greve atingiu grandes proporçôes, paralisando praticamente toda a capital e centenas de indústrias na regiáo vizinha do $\mathrm{ABC}$ e em várias cidades do interior de São Paulo. Enormes piquetes, alguns compostos por milhares de operários, garantiam a eficiência do movimento percorrendo os grandes corredores industriais da cidade e, na esmagadora maioria dos casos, convencendo os operários a aderir.

Os piquetes tomaram conta de São Paulo durante aqueles dias. Inicialmente organizados pelos sindicalistas e lideranças nos locais de trabalho, rapidamente se multiplicaram, apoiados nas várias redes informais, de amizade e vizinhança dos próprios trabalhadores. A cada fábrica paralisada, em vez de se dispersarem, os trabalhadores preferiam engrossar o piquete. Seu efeito de demonstraçáo era poderoso, estimulando a solidariedade e a segurança dos trabalhadores contra a repressão policial. "Achei que devia entrar na greve para acompanhar meus companheiros. Não fica bem companheiro de serviço, vendo seus colegas se sacrificar, deixar de cooperar", justificava um jovem operário que aderira ao movimento logo após a ação de um piquete. ${ }^{8}$

Esta participação maciça ultrapassou em muito as mais otimistas previsóes dos próprios sindicalistas. No dia 16, a paralisação ampliou-se ainda mais e o movimento ganhou ares de verdadeira rebelião popular, escapando em parte ao controle dos próprios sindicatos. Não apenas os trabalhadores em greve, mas a população em geral tomou conta das ruas, protestando contra suas condições de vida. O ambiente relativamente pacífico do dia anterior foi substituído por cenas de violência. Fábricas foram depredadas e choques entre seguranças das empresas e os manifestantes resultaram em mais de 50 feridos.

A dimensão que a greve adquiriu assustou os próprios dirigentes sindicais. O PUI se viu obrigado a lançar um manifesto condenando as violências cometidas, ao mesmo tempo em que tomava medidas para acalmar os ânimos e controlar o movimento. Pressionado pelos empresários e pelo governo federal, o governador Jânio Quadros modificou sua disposição inicial de não reprimir a greve. A ostensiva presença policial a partir do terceiro dia não arrefeceu a paralisaçấo, que continuou com altos índices de adesão, mas certamente foi um fator decisivo para a diminuição de depredaçôes e incidentes violentos nas portas de fábrica. Os piquetes continuaram a ter atuação decisiva, mas passaram a ser monitorados mais de perto pelo comando sindical que, reiteradamente, clamava por calma e que os operários evitassem provocaçóes de choques com a polícia e os patrôes. De toda forma, a disposição dos trabalhadores era também reafirmada em grandes assembleias no Estádio Distrital da Mooca (antigo Hipódromo). Com as ruas fortemente vigiadas, eles desmentiam na prática o argumento empresarial de que a greve só ocorrera devido à ausência da polícia.

Ainda que fosse uma forma de ação recorrente no movimento sindical brasileiro durante paralisaçôes de trabalho, a quantidade de piquetes e a participação dos operários em suas atividades durante a "greve dos 400 mil" causou forte impressão entre os contemporâneos.

${ }^{8}$ Notícias de Hoje, 16 de outubro de 1957. 
Mesmo setores conservadores reconheciam o papel estratégico que os piquetes tinham para o sucesso da parede. Avaliando o primeiro dia de greve, o tradicional jornal $O$ Estado de $S$. Paulo, por exemplo, afirmava que a "ação dos piquetes da greve é cada vez mais eficiente e em $90 \%$ dos casos, sua presença conduz à paralisação do serviço". O cônsul estadunidense reconhecia que a paralisação estava "extremamente bem organizada" graças à ação dos piquetes. A própria federação patronal (Fiesp) não tinha como negar que grande parte das "firmas associadas" estava impedida de trabalhar "por piquete". As lideranças operárias, obviamente, também destacavam a ação dos piquetes para o sucesso da paralisação. Antônio Chamorro, líder teceláo comunista, em seu discurso no dia do encerramento do movimento, celebrava o "trabalho dos piquetes, a grande arma da greve."

Para os setores empresariais, no entanto, o reconhecimento da força dos piquetes implicava caracterizá-los como violentas formas de ação, estranhas e alheias ao operário comum. Os piquetes, capitaneados por "baderneiros" e incentivados por "políticos demagogos" coagiriam ordeiros operários a aderir ao movimento. Distinguir os piqueteiros dos "reais" trabalhadores era a operação discursiva recorrente na fala patronal. Antônio Devisate, presidente da Fiesp, em ofício dirigido ao governador do estado, é emblemático neste sentido:

Infelizmente, grupos de agitadores percorrem os bairros industriais chegando a verificarem-se invasões de fábricas, depredaçóes e outras violências, e pelo temor e coação forçam os operários a abandonar o serviço. ${ }^{11}$

De qualquer forma, o impasse das negociaçôes entre patrôes e trabalhadores só seria resolvido com a intervenção do Tribunal Regional do Trabalho (TRT). No dia 24 de outubro, décimo dia da paralisação, o TRT concedeu $25 \%$ de reajuste aos grevistas. Reunidos em assembleia na praça Roosevelt, os operários efusivamente aprovaram o fim da greve e saíram em passeata comemorando a conquista pelas ruas do centro da cidade. Os meses de novembro e dezembro ainda assistiriam a uma onda de greves por empresas contra demissóes motivadas pela paralisaçáo e o não pagamento do reajuste. Em janeiro de 1958, o Tribunal Superior do Trabalho acataria recurso dos industriais e reduziria o reajuste para 18\%. Apesar dos vários protestos, uma nova greve geral das categorias não foi convocada e a busca pelo aumento salarial foi concentrada em cada indústria.

Boa parte da força e repercussão da greve dos 400 mil se deveu ao apoio que ela conseguiu angariar na sociedade. Diversas entidades estudantis, comunitárias, associaçóes de bairro, entre outras, manifestaram sua solidariedade e reconheciam a legitimidade das reivindica-

\footnotetext{
${ }^{9}$ O Estado de S. Paulo, 16 de outubro de 1957; The São Paulo Strike of October, 1957, Amcongen, São Paulo, Brasil, Arquivo Nacional, GRDS, RG59, cx. 4308, 832. 06/3-1058, p. 6; Boletim Informativo Fiesp/Ciesp, 28 de outubro de 1957.

${ }^{10}$ Notícias de Hoje, 25 de outubro de 1957.

${ }^{11}$ Boletim Informativo Fiesp/Ciesp, 28 de outubro de 1957.
} 
çôes operárias. A simpatia da população em geral também era evidente. Manifestaçóes de apoio e o envio de alimentos para os grevistas foram comuns durante a paralisação, como na passeata conjunta de estudantes e trabalhadores no dia 23 de outubro no centro da cidade. Cantando o hino nacional e levando à frente uma imensa bandeira brasileira desfraldada, os manifestantes angariavam contribuiçóes e donativos para os trabalhadores em greve.

O momento político também favorecia os grevistas. Atores centrais na vida pública e nas definiçôes eleitorais, os trabalhadores e seus sindicatos eram cortejados por diferentes forças políticas. As principais lideranças políticas locais, o governador Jânio Quadros e o prefeito Adhemar de Barros, ambos com pretensôes presidenciais, competiam pela simpatia do voto operário e deram diferentes formas de apoio à greve. O governo federal do presidente Juscelino Kubitscheck, embora preocupado com as repercussôes do movimento grevista, mantinha uma postura ambígua, mas também procurava não passar uma imagem de hostilidade aberta aos trabalhadores e suas lideranças. João Goulart, o vice-presidente, chegou, inclusive, a manifestar seu apoio às reivindicaçóes sindicais. Era um tempo em que quase nenhum político, por medo, demagogia ou razóes ideológicas, ousava ser abertamente contra uma manifestação operária daquele vulto. Muitos, inclusive, chegaram a participar de piquetes, como num famoso caso da fábrica Alpargatas, mencionado a seguir.

\section{"Piquetes do sindicato", "piquetes naturais" e "piquetes monstros” em 1957}

Entrevistado por um sociólogo em novembro de 1958, cerca de um ano após a "greve dos 400 mil", um ativista metalúrgico detalhava o cotidiano do protesto e a importância dos piquetes para o sucesso da paralisação. Geralmente, lembrava ele, os piquetes eram liderados "por delegados dos trabalhadores junto ao sindicato [...]. O delegado serve de elemento de ligação entre operários e sindicatos". Baseado nas informaçóes dadas pelo militante, o entrevistador concluiu que "o conjunto total do piquete era constituído por pessoas que já mantinham relaçôes de há muito. Era uma condição para que se mantivesse coeso, tanto na parte disciplinar como uniformidade". ${ }^{2}$

Entretanto, esta suposta disciplinada organização operária não tinha como dar conta da dimensão de uma greve tão ampla e generalizada, tanto em termos geográficos quanto na abrangência de setores industriais e categorias de trabalhadores envolvidas. Assim, a presença de piqueteiros "espontâneos" ou "voluntários" teria um papel central na dinâmica do movimento. Arregimentados, no mais das vezes, nas manifestaçôes coletivas da própria greve, como assembleias, passeatas ou aglomeraçóes nas portas de fábricas, esses operários aderiam aos piquetes organizados pelos sindicatos ou formavam novos. Disseminaram-se pelos corredores

\footnotetext{
${ }^{12}$ Entrevista com "chefe de piquete", Sindicato dos Metalúrgicos de São Paulo, 5 de novembro de 1958. Fundo Fábio Munhoz, Cedem-Unesp.
} 
industriais da cidade, conquistando novos adeptos para a paralisação e piquetes, ocupando o espaço público e garantindo a manutenção de uma greve massiva por vários dias.

Diversos estudos hoje demonstram que o movimento sindical, ao longo dos anos 1950 e início dos 1960, estruturou uma razoável rede de organização operária no interior das fábricas, apesar das limitaçóes impostas pela legislação trabalhista (em grande parte concebida justamente para evitar qualquer tipo de organização deste tipo) e da forte repressão patronal e policial. Em sua grande maioria, essas formas de organização dos trabalhadores eram informais e clandestinas, mas desempenhavam um papel decisivo para uma maior democratização da vida sindical. Quando da eclosão de movimentos de ação coletiva, era o acionamento de tais organizaçôes que, em grande medida, garantia a eclosão, a sustentação e o apoio dos trabalhadores ao movimento.

Delegados sindicais, comissóes de empresa e salários, diretores ou suplentes de diretoria não afastados da produção cumpriam a tarefa de ligação entre o interior das fábricas e a cúpula sindical. Eram referências para os demais trabalhadores, divulgando, de um lado, informaçôes sobre as atividades sindicais e, de outro, funcionando, para as direçôes sindicais, como uma espécie de "termômetro" do clima das bases no cotidiano das empresas.

Nas greves do período e, em particular na "greve dos 400 mil", eram esses trabalhadores que lideravam e organizavam os piquetes. Arregimentando os colegas mais próximos, foram vários desses núcleos que, partindo das sedes dos sindicatos, se dirigiram às fábricas sindicalmente mais organizadas e mais propensas à greve, partindo em seguida pelos corredores industriais da cidade, conquistando a paralisação das atividades. Rapidamente, os piquetes se transformaram em grandes manifestaçôes públicas, com a presença de milhares de trabalhadores nas ruas vagando pelas regióes operárias.

Para os trabalhadores, em uma cidade com as dimensóes de São Paulo, os piquetes serviam também como uma garantia de que a greve estava acontecendo e de que eles poderiam aderir sem correr o risco de ficarem isolados ou de que apenas a fábrica onde trabalhavam paralisaria as suas atividades, sofrendo consequentemente as prováveis represálias patronais. Ademais, nos piquetes, assembleias e manifestaçôes de rua, o trabalhador isolado sentia-se participando de uma coletividade, ampliando um senso de identidade comum. Os piquetes funcionavam assim, como uma espécie de "biombo" coletivo que protegia os trabalhadores individualmente das represálias por aderir ao movimento. Mesmo um analista contemporâneo cético em relação ao grau de consciência de classe entre os trabalhadores paulistanos reconhecia que durante a greve em 1957

a alegação [dos operários] de não virem trabalhar para evitar 'encrenca' [com os sindicatos e os piquetes] era, em parte, uma desculpa que davam a seus chefes para participarem do movimento grevista. ${ }^{13}$

\footnotetext{
${ }^{13}$ Cf. LOPES, Juarez Brandão. O ajustamento do trabalhador à indústria: mobilidade social e motivação.
} 
Certamente, a ausência de repressão policial nos primeiros dias de greve colaborou para a generalização e expansão geográfica da paralisação em pouco tempo. Facilitou também a proliferação dos piquetes que extrapolou os mecanismos de organização criados pelos sindicatos. Na linguagem de uma liderança operária do período, a partir de um dado momento os piquetes não se limitavam apenas aos do "sindicato", mas passaram a surgir os piquetes "naturais". Segundo ele, "no decorrer da greve, foi se modificando para o voluntariado [...]. Eram dezenas e dezenas destes piquetes [naturais]. Era o tipo mais eficiente; eram eles que nos informavam o crescimento ou diminuição dos grevistas". ${ }^{14}$

Em 1957, há claramente um padrão de organização dos piquetes, que surgem incialmente a partir da direção sindical, sua representação nas fábricas e do núcleo de trabalhadores mais próximos ao sindicato, mas rapidamente alcançam uma dimensão e participação voluntária impressionante que, frequentemente, espantou e assustou as próprias lideranças sindicais e políticas, especialmente a partir do segundo dia do movimento, quando a greve ganhou ares de rebeliāo popular e episódios de violência tornaram-se mais comuns.

Os contatos informais entre os próprios trabalhadores cumpriam papel fundamental na ampliação dos piquetes. Como salientou um líder do sindicato dos vidreiros, na maioria dos casos "era a primeira vez" que estes trabalhadores participavam de um piquete. "Às vezes", prosseguia o sindicalista,

havia uma coisa gozada: a gente orientava para que os trabalhadores fossem com calma, mas alguns chegavam como se fossem o governador. Falavam com o patrão: "tem que fechar". A maioria deles já era conhecida do sindicato. Alguns não. Eram apresentados pelos companheiros de fábrica: "olhe, esse aqui é conhecido nosso lá da fábrica". Aí a gente aceitava o elemento. ${ }^{15}$

Para além das fábricas e locais de trabalho, a greve também se articulava nos bairros populares e pelo tecido urbano da cidade. Clubes de futebol amador, associaçóes de moradores e variados movimentos sociais informais foram importantes espaços de apoio, troca de informaçôes e mesmo de organização do movimento e de piquetes. Relaçôes de amizade, parentesco, vizinhança, conterraneidade eram acionadas pelos trabalhadores que enxergaram na greve uma poderosa forma de protesto contra a situação de exploração nas empresas, os baixos salários e alto custo de vida, mas também contra a cotidiana segregaçáo social e urbana.

Nem sempre, porém, os piquetes resultavam em adesão ativa e participação dos trabalhadores. Muitos gerentes e patróes eram convencidos a liberar os operários para evitar confusão ou confrontos com os grevistas. Nas muitas empresas onde a presença do sindicato era pe-

In: HUTCHINSON, Bertram. Mobilidade e trabalho: um estudo na cidade de São Paulo. Rio de Janeiro, Centro Brasileiro de Pesquisas Educacionais, 1960.

${ }^{14}$ Entrevista com "chefe de piquete", Sindicato dos Vidreiros de São Paulo, outubro de 1958. Fundo Fábio Munhoz, Cedem-Unesp.

${ }^{15}$ Idem. 
quena, era o poder de intimidação dos piquetes que, muitas vezes, forçava a paralisação das atividades. Coagidos e constrangidos pela multidáo, trabalhadores desejosos de comparecer ao trabalho recuavam e patróes, muitas vezes, avaliavam que era melhor parar a produção para evitar maiores prejuízos.

Foi o que aconteceu, por exemplo, na Cerâmica Sáo Caetano, onde trabalhava o entáo jovem operário José de Souza Martins, que anos depois se tornaria professor de sociologia da Universidade de São Paulo. Em sua autobiografia, Martins recorda-se do piquete na porta da fábrica durante a greve de 1957, "uma multidão, aos gritos" invadindo a fábrica. "Em poucos minutos", relembra, "aquela massa imensa estava dentro, correndo pelas ruas internas e dirigindo-se às diferentes seçôes, paralisando tudo e expulsando os operários para fora". Atemorizados, os engenheiros da empresa correram "para as seçôes invadidas e aconselharam os operários a saírem pacificamente [...]. Rapidamente a fábrica ficou vazia e em silêncio," conclui (cf. MARTINS, 2011: p. 409-411). ${ }^{16}$

No entanto, muitos industriais e gerentes de fábricas, assim como operários que por variadas razôes não desejavam a greve, decidiram resistir às investidas dos piquetes. Este foi um dos cenários mais comuns de conflitos e violências durante a greve em 1957, em particular em seus primeiros dias. Variados confrontos com seguranças particulares das empresas ou mesmo com os próprios proprietários foram reportados na imprensa. Piquetes foram recebidos a tiros em muitas fábricas e grevistas chegaram a ser baleados em vários destes incidentes, acirrando ainda mais os ânimos e uma sensaçáo de descontrole da violência. ${ }^{17}$

As medidas tomadas pelos dirigentes sindicais, a partir do terceiro dia de paralisação, procurando conter os ânimos mais exaltados e controlar mais a proliferaçáo dos piquetes "naturais", através da identificação dos piqueteiros por meio de carteirinhas emitidas pelos sindicatos, respondiam não apenas às pressóes governamentais e policiais, mas indicavam também que a dimensão atingida pela greve igualmente os surpreendia. As açôes violentas ocorridas principalmente no segundo dia de greve pareciam ultrapassar os limites tolerados pelos dirigentes e ativistas sindicais. Um experiente piqueteiro metalúrgico contava que, naqueles conturbados dias,

a maior dificuldade era a de fazer os novos elementos reconhecerem o caráter pacífico do movimento, pois caso contrário haveria a possibilidade de intervenção da polícia, o que minava a coesão e unidade do grupo, com a dispersão de muitos membros. ${ }^{18}$

\footnotetext{
${ }^{16}$ MARTINS, José de Souza. Uma arqueologia da memória social. Autobiografia de um moleque de fábrica. São Paulo: Ateliê Editorial, 2011, p. 409-411.

${ }^{17}$ Analisando uma série de casos deste tipo, Murilo Leal levanta a hipótese de que a maioria das açóes violentas na greve de 1957 decorreram deste tipo de reação patronal. Cf. NETO, Murilo Leal Pereira. A reinvenção da classe trabalhadora (1953-1964), op. cit., p. 280-2811. Outras situaçóes similares foram relatadas por NEGRO, Antonio Luigi. Linhas de montagem. O industrialismo nacional-desenvolvimentista e a sindicalização dos trabalhadores, op. cit., p. 105-109.

${ }^{18}$ Entrevista com "chefe de piquete", Sindicato dos Metalúrgicos de São Paulo, 5 de dezembro de 1958. Fundo Fábio Munhoz, Cedem-Unesp.
} 
Além de estimular a repressão policial, a violência dos grevistas questionava o discurso oficial das lideranças de uma greve justa e pacífica e colocava, assim, em risco a própria legitimidade da paralisação e o amplo leque de apoios costurados pelos sindicalistas junto à sociedade civil, os meios políticos e setores do próprio governo.

Se o "caráter pacífico" do movimento grevista era reiteradamente repetido nos discursos públicos das lideranças e ativistas operários, um certo grau de violência e intimidação eram aceitos e certamente esperados no cotidiano da greve, em particular na açáo dos piquetes. De um lado a açáo violenta era consentida e considerada justa como reação à constante violência repressiva da polícia, sistematicamente apoiada e estimulada pelos patróes, a "aliança empresarial-policial” (NEGRO, 2004). Por outro lado, alguma situaçáo de violência moderada por parte dos piquetes poderia servir de estopim para que os trabalhadores nas fábricas pudessem parar suas atividades, usando como justificativa o temor da ação dos grevistas. Neste sentido, o depoimento de um dirigente sindical daquele período sobre a ação dos piquetes é elucidativo:

Era a turma toda andando pela rua, [...] em piquete, a gente andando pela rua. Jogaram pedra nessa primeira firma, jogaram uma pedra lá que furou e quase pega na cabeça do dono da firma [...]. A turma tava doida prá sair mesmo, rapaz, porque eles não queriam dar aumento prá gente. Todo mundo saiu. [Os trabalhadores] davam graças a Deus quando eles [os piqueteiros] chegavam na firma e mandavam todo mundo sair. Ou sai ou apanha (risos). ${ }^{19}$

A violência como punição moral contra os fura-greves também era disseminada e seu uso moderado era implicitamente admitido como uma das funçóes dos piquetes. Um relatório policial, por exemplo, reportava que no bairro operário de Sáo Miguel Paulista

piquetes de grevistas praticaram atos de violência contra os chamados "fura-greves", visando de preferência operárias as quais esguichavam através de bisnagas tinta ou substância vermelha, possivelmente iodo-cromo [...] alguns piquetes tentaram até pichar cabelos das moças "furonas". ${ }^{20}$

Um curioso relato de um ativista metalúrgico, identificado pelo entrevistador no final de 1958 como "o loiro", é bastante significativo de como a violência moderada e de caráter moral punitivo poderia não apenas ser tolerada, mas ter um papel "pedagógico". Entrevistado juntamente com outro colega que (pelo menos diante do entrevistador) dizia discordar da ação violenta eventualmente empreendida pelos piquetes contra fura-greves, "o loiro"

\footnotetext{
${ }^{19}$ Entrevista de José Luiz dos Santos, apud NETO, Murilo Leal Pereira. A reinvenção da classe trabalhadora (1953-1964), op. cit., p. 338.

${ }^{20}$ Cf. FONTES, Paulo. Trabalhadores e cidadãos. Nitro Química: a fábrica e as lutas operárias nos anos 50. São Paulo: Annablume, 1997.
} 
respondia que "com alguns companheiros não adianta argumentar, que só a força resolvia nestes casos". Como exemplo, contou o caso de sua própria cunhada, uma operária que nunca havia participado de movimento paredista nenhum. E prosseguia,

ela é dessas portuguesas que só querem ter dinheiro para comprar sua casinha; quando as outras faziam greve, ela ia trabalhar e ganhava o dobro. E não adiantava nada argumentar com ela. Um dia, as companheiras delas pegaram-na na saída e lhe deram uma surra de guardachuva. Ela ficou tão assustada que em qualquer coisa ela é a primeira a parar.

E "o loiro" concluía, "por isso, com gente assim , só na força mesmo."21

Se a violência seletiva e moderada podia ser aceita, embora raramente anunciada, era a imagem de unidade e coesão da classe operária que os dirigentes sindicais procuravam associar aos piquetes. Os chamados "piquetes monstros" eram oportunidades de reafirmar a presença pública dos trabalhadores e demonstrar a força da greve. Frequentemente, organizados após grandes assembleias operárias, os "piquetes monstros" em geral tinham um caráter festivo, reunindo milhares de trabalhadores em uma espécie de "carnaval da greve", produzindo um poderoso efeito ritualístico de manifestação pública permanente. Um "chefe de piquetes" recordava um pouco deste ambiente, lembrando que, em um dos "três piquetes monstros" organizados pelo sindicato dos vidreiros, milhares de trabalhadores se reuniram diante de duas das maiores indústrias da categoria, "a Santa Marina e a Vidrobrás",

Aí, nós levamos a bandeira da Federação dos Vidreiros, uma bandeira grande, bonita, vermelha. Fizemos desfile diante das fábricas e ficamos três horas falando [...] esse piquete foi muito bonito. ${ }^{22}$

$\mathrm{Na}$ maior parte das vezes, os "piquetes monstros" eram especialmente preparados para atingir empresas específicas. Grandes fábricas que por alguma razão ainda não tivessem paralisado suas atividades, indústrias de propriedade de representantes dos sindicatos empresarias e/ou amplamente reconhecidas por más condiçôes de trabalho ou despotismo patronal foram alvos frequentes desses piquetes.

Um caso que se tornou lendário foi o do "piquete monstro" organizado em 22 de outubro no bairro da Mooca, após uma grande assembleia geral das várias categorias de trabalhadores em greve. Por volta de 15 mil trabalhadores percorreram as ruas do bairro e se dirigiram para a fábrica têxtil São Paulo Alpargatas, considerada pelos sindicalistas como "um velho baluarte patronal em todas as greves". ${ }^{23}$ Contando com o vice-governador Porfírio da Paz

\footnotetext{
${ }^{21}$ Relatório de conversa informal realizada com “chefes de piquetes”. Sindicato dos Metalúrgicos de São Paulo, dezembro de 1958. Fundo Fábio Munhoz, Cedem-Unesp.

${ }^{22}$ Entrevista com "chefe de piquete", Sindicato dos Vidreiros de São Paulo, outubro de 1958. Fundo Fábio Munhoz, Cedem-Unesp.

${ }^{23}$ Notícias de Hoje, 23 de outubro de 1957.
} 
e vários outros políticos na linha de frente do piquete, os dirigentes sindicais conseguiram convencer a gerência da empresa a suspender a produçáo e liberar os operários e operárias, que foram recebidos com incontido entusiasmo pela multidáo na porta da fábrica. ${ }^{24}$

Em 1957, os "piquetes monstros" igualmente foram uma oportunidade tanto para os sindicalistas comprovarem sua capacidade de angariar apoio político quanto para várias autoridades públicas e figuras políticas demonstrarem um suposto comprometimento com os trabalhadores e suas lutas. Além de minar o ímpeto da repressão policial e patronal, a presença de vereadores, deputados e até de um vice-governador em atividades dos grevistas ajudava a dar respeitabilidade ao movimento e reforçava o discurso sindical de uma greve ordeira, pacífica e justa. Ademais, uma adesão ampla de políticos e representantes da sociedade civil em geral dava legitimidade a uma greve prestes a ser julgada no tribunal do trabalho. Os piquetes se tornavam, assim, um importante espaço de visibilidade política com amplas repercussóes. Em um cenário em que várias forças disputavam acirradamente o voto operário, a greve (e sua expressão visível nas ruas, os piquetes) foi um decisivo momento de politização e presença dos trabalhadores na arena pública.

\section{A "greve dos 41 dias" dos metalúrgicos do ABC Paulista, 1980}

A greve empreendida em 1980 pelos metalúrgicos do ABC paulista, área fabril da regiáo metropolitana de Sáo Paulo que concentrava na ocasião quase toda a indústria automobilística brasileira, vem sendo entendida nos últimos 30 anos como uma das mais importantes mobilizaçôes do operariado brasileiro. Náo é de espantar, portanto, que a greve de 1980 — assim como as de 1978 e a de 1979 — tenha recebido, imediata e posteriormente, uma avalanche de estudos acadêmicos que, esmiuçando-a em seus múltiplos aspectos, legaram-no uma vasta e diversificada bibliografia.

A partir de meados dos anos 1970, o modelo econômico implantado pelo regime militar começou a dar sinais de esgotamento. Pressionado por uma crise econômica e pelas crescentes demandas por redemocratização de diversos setores da sociedade civil, o governo, ainda que com dissensôes internas, iniciou um processo de liberalização política controlada que ficaria conhecido como "abertura". Nesse espaço público ligeiramente alargado, os movimentos populares intensificaram suas açóes reivindicatórias e as greves metalúrgicas do ciclo 1978-1980 irromperam. Desse modo, ainda que com um conteúdo próprio - enfatizando, por exemplo, os direitos sociais —, os trabalhadores se incorporavam à luta pela redemocratização do país, abalando os arranjos políticos que até então modelavam a "abertura".

\footnotetext{
${ }^{24}$ Última Hora, 22, 23 e 24 de outubro de 1957. Ver também NETO, Murilo Leal Pereira. A reinvenção da classe trabalhadora (1953-1964), op. cit., p. 275-276 e NEGRO, Antonio Luigi. Linhas de montagem. O industrialismo nacional-desenvolvimentista e a sindicalização dos trabalhadores, op. cit.
} 
Quando, em 1978, os metalúrgicos do ABC paulista cruzaram os braços diante de suas máquinas e se recusaram a trabalhar, eles romperam uma década de silêncio imposto, pela força, à classe trabalhadora brasileira e abriram o caminho para milhares de greves em todo o país. É certo que, nos anos anteriores, numerosas mobilizaçôes haviam sido empreendidas por outros operários em seus locais de trabalho. Elas não ganharam, todavia, a escala e a visibilidade assumidas pelo evento de 1978. Algo que se repetiria na greve de 1979 e, especialmente, na de 1980. Esta assumiu ares de um confronto aberto contra o regime autoritário, atraindo, portanto, amplo apoio dos diversos setores que se punham a favor da redemocratização do país.

Em 1ํ de abril de 1980, aproximadamente 300 mil metalúrgicos do ABC paulista e de algumas cidades do interior do estado de Sáo Paulo entraram em greve frente ao não atendimento pelos patrôes de suas reivindicaçóes (aumento salarial de 7\% pela produtividade e estabilidade no emprego por 12 meses). Durante 41 dias, eles resistiram à ampla repressáo que lhes foi lançada pelos patróes e pelo regime militar, a qual muito colaborou para que a mobilização coletiva dos trabalhadores se espraiasse pelo espaço urbano - especialmente, pelas ruas do $\mathrm{ABC}$ paulista região com elevada concentração de moradias operárias. ${ }^{25}$ Expulsos das fábricas e de importantes espaços públicos, os metalúrgicos mantiveram a greve a partir, principalmente, dos bairros em que residiam, fomentando a politizaçáo de espaços e relaçôes de suas vidas cotidianas e redefinindo a geografia da mobilizaçáo coletiva. ${ }^{26}$ Assim como na "greve dos 400 mil" e em outros grandes movimentos grevistas da região metropolitana de Sáo Paulo na segunda metade do século XX, na "greve dos 41 dias" a ação dos piquetes se mostrou decisiva, atraindo sobre eles múltiplos olhares dos quais se originaram interpretaçóes divergentes a seu respeito.

Os órgãos da imprensa escrita, quando buscaram caracterizar e definir o papel dos piquetes na mobilização operária, esboçaram opiniôes heterogêneas. A Vanguarda, periódico de São Bernardo do Campo que adotou uma postura cambiante frente à greve, fornece-nos uma ideia dos tons disponíveis. Nos primeiros dias da parede, claramente apoiando o movimento, A Vanguarda afirmava: "a greve continua, pacífica e ordeira. Sem piquetes no início, com piquetes a partir de ontem”. Sugere-se, portanto, uma harmonia entre trabalhadores em greve e piquetes, cuja atuação, notemos, não retirava da parede seu caráter "pacífico e ordeiro". Duas semanas depois, criticando o não cumprimento da decisão do Tribunal Regional do Trabalho (TRT) que decretou a ilegalidade do movimento e retirando seu apoio à parede metalúrgica, $A$ Vanguarda mudava sua posiçấo e concluía: "Com piquetes, a greve forçada." Por meio dos piquetes, "líderes do movimento" estariam impondo a greve, "aproveitando-se da ignorância da massa". Desse modo, fica esboçado um antagonismo entre

\footnotetext{
${ }^{25}$ RAINHO, Luis Flávio. Os peóes do grande ABC. Petrópolis: Vozes, 1980.

${ }^{26}$ MACEDO, Francisco Barbosa. A greve de 1980: redes sociais e espaço urbano na mobilização coletiva dos metalúrgicos de São Bernardo do Campo. Mundos do Trabalho, Florianópolis, v. 3, n.5, p. 136-165, jan./ jun. 2011.
} 
trabalhadores em greve e piqueteiros. Na semana seguinte, admitindo que as "autoridades governamentais" haviam se excedido na repressão ao movimento, $A$ Vanguarda qualificava as açôes operárias para manutenção da greve, entre as quais o jornal incluía os piquetes, como "atitude de defesa". Nesse momento, portanto, os piquetes, ainda que possam contar com "esquerdistas" infiltrados, são apresentados como um dos elementos da resistência dos trabalhadores em greve à dura repressão estatal que lhes foi lançada. Mais uma vez, então, sugere-se a sintonia entre piquetes e trabalhadores em greve. Finalmente, nos últimos dias da parede, $A$ Vanguarda registrava que os piquetes ainda continuavam atuando e abria espaço para que lideranças da "Greve dos 41 dias" atribuíssem episódios de violência operária a policiais infiltrados entre os grevistas. ${ }^{27}$

Como se vê, as lideranças da parede empenhavam-se para caracterizar os grevistas como "pacíficos e ordeiros". Assim, nas assembleias gerais públicas evitaram falar abertamente sobre os piquetes, mas, nas reunióes mais reservadas, estimulavam, organizavam e os admitiam como necessários e constitutivos da mobilização operária. Atribuindo-lhes o papel de conter os fura-greves, contra os quais se admitia até o uso moderado de violência física, os piquetes eram vistos como decisivos para o êxito da greve. ${ }^{28}$

As autoridades policiais, por sua vez, oscilaram em suas interpretaçôes. A princípio, os piquetes seriam, como igualmente especulavam membros dos governos federal e estadual, uma das formas pelas quais as "correntes políticas marxistas" se infiltrariam na parede metalúrgica, manipulando-a. ${ }^{29}$ Entretanto, diante da insuficiência desta explicação frente às incontáveis evidências de piquetes organizados por iniciativa dos próprios trabalhadores, as autoridades policiais passaram a afirmar que os piqueteiros eram ingênuos, "os mais incautos" entre os operários, que se deixavam levar pelas recomendaçóes de lideranças grevistas irresponsáveis. ${ }^{30}$

Se, para alguns operários o piquete era uma maneira privilegiada de se engajar na mobilização coletiva, para muitos outros, ele era visto como um importante anteparo - uma vez que "explicava" sua ausência ao trabalho —, diante das ameaças e pressóes de Estado/ patrôes, para que pudessem participar da greve sem assumir a pecha de "grevista". Assim, nas três primeiras semanas da parede, por meio de simples "convencimento" e "convite social”, piquetes compostos por menos de uma dezena de operários dissuadiram, não raramente, centenas de trabalhadores de exercerem normalmente suas atividades. ${ }^{31}$

\footnotetext{
${ }^{27}$ Cf. respectivamente $A$ Vanguarda, ediçóes de 5, 19, 26 de abril e 10 de maio.

${ }^{28}$ Relatório para a Delegacia Seccional de Polícia do ABCD. Ref. Reunião na Sede do SMSBCD, em 01/04/1980. s/d. Dossiê 50-Z-341 (Pasta 22) e ABC da greve. Direção: Leon Hirszman. Brasil, 1979. DVD. (75 minutos).

${ }^{29}$ Cf. Folha de S. Paulo, 6 e 8/5/1980 e Relatório I. P. n. 15/80. Divisão de Ordem Social - DEOPS/SP. Prontuário 149.689 (v. 1), fl. 5.

${ }^{30}$ Relatório I.P. n. 25/80. Divisão de Ordem Social — DEOPS/SP. 16/5/1980. Prontuário 149.689 (v. 2), fl. 11. ${ }^{31}$ Cf. Diário do Grande ABC, 17/4/1980; Auto de prisão em flagrante delito de Manoel G. V. Del. Pol. de São Bernardo do Campo. 29/4/1980. OS — 0099; Termo de declaraçóes de Manoel Abílio Brandão. Del. Pol.
} 
Tais açôes são mais compreensíveis quando temos em mente que o Estado, amparado em ampla legislação autoritária, ainda tendia, apesar das oscilaçóes, a tratar greves como crimes. Os patrôes não ficavam atrás: frequentemente expulsavam os trabalhadores das fábricas e chamavam a polícia para que esta, em vias públicas, com cassetetes e revólveres, pudesse fazer a separação - temida pela maior parte dos operários devido às puniçôes em que poderia redundar - entre "grevistas" e "trabalhadores". ${ }^{32}$ A ação dos piquetes borrava, insistentemente, essa distinçâo. Portanto, se tinham os fura-greves como alvos claramente definidos, os piquetes não deixaram de colocar eficientes obstáculos às pretensôes do Estado e dos empregadores de lançarem a "pecha" de grevista — e suas decorrências — sobre aqueles que aderiram à parede metalúrgica.

A articulação tácita entre piqueteiros e demais grevistas não pode, de modo algum, ser generalizada para a totalidade dos operários metalúrgicos, nem para a greve de $1980 \mathrm{em}$ toda sua duração. Em diversos episódios, trabalhadores se sentiram simplesmente coagidos por piqueteiros. A partir de 30 de abril, por exemplo, quando muitos operários, ameaçados com a possibilidade de demissão sem quaisquer direitos, em função de uma questionável interpretação da legislação trabalhista por parte dos patróes, avaliaram que era hora de retornar ao trabalho, ${ }^{33}$ os piqueteiros intensificaram suas açóes, fomentando diversos conflitos. Nesse sentido, os piquetes também evidenciam contradiçóes inerentes a qualquer mobilizaçáo coletiva. De maneira preponderante, contudo, eles tiveram o importante papel de sopesar as ameaças e pressôes de Estado e patrôes, abrindo espaço para que os operários, baseados em uma constante avaliação do equilíbrio circunstancial do campo de forças, pudessem deliberar e inserir suas escolhas/açôes sobre aderir ou permanecer em greve.

Nesse complexo e vigoroso conjunto de pressōes, os metalúrgicos do ABC paulista paralisaram o trabalho por 41 dias e impuseram prejuízos colossais às empresas, que receberam aportes financeiros do governo federal, interessado em impor uma exemplar derrota aos grevistas. Os operários, após a longa parede, retornaram às fábricas sem terem suas reivindicaçôes atendidas. Para muitos deles, a penúria se intensificou com o início das demissóes após o retorno ao trabalho. ${ }^{34}$ Por sua vez, os mais importantes dirigentes do sindicato, entre eles Lula, estavam presos.

Em que pese seu fim melancólico e custoso para os trabalhadores, a greve de 1980 fomentou avaliaçóes e processos entendidos como positivos para muitos de seus coetâneos, enfatizando tanto a politização do cotidiano e a busca de autonomia quanto a participação

de São Caetano do Sul. 30/4/1980. OS — 0097; Termo de declaraçôes de Isaías C. V. Pol. de São Caetano do Sul. 30/4/1980. OS — 0097; BO n. 1.642 emitido pela Chefia de Segurança Industrial da Volkswagen. 02/5/1980. OS - 1148 e Camargo, 2003, 2003.

${ }^{32}$ Cf. RAINHO, Luis Flávio e BARGAS, Osvaldo. As lutas operárias e sindicais dos metalúrgicos em São Bernardo (1977-1979). São Bernardo do Campo: Associação Beneficente e Cultural dos Metalúrgicos de S. Bernardo do Campo e Diadema, 1983, p. 213. v. 1.

${ }^{33}$ Cf. Relatório para a Delegacia Seccional de Polícia do ABCD. OS - 1148 e Folha de S. Paulo, 6 e 7/5/1980.

${ }^{34}$ Folha de S. Paulo, 13/05/1980 e ABCD Jornal, 17/06/1980. 
dos trabalhadores no sistema político para assegurar e ampliar suas possibilidades de atuação institucional. Avaliaçôes que deram novo impulso ao processo de fundação do Partido dos Trabalhadores (PT) e tiveram amplas repercussóes na configuração do Brasil contemporâneo (cf. SADER, 1988 e MENEGUELLO, 1989). ${ }^{35}$

\section{Piquetes em ação na greve de 1980: padróes de ação e usos da violência}

$\mathrm{Na}$ "Greve dos 41 dias", os piquetes se constituíram a partir da mobilização de um variado espectro de vínculos sociais, atuaram em diversos espaços e empregaram múltiplos recursos de coação. Convencimento argumentativo, coação moral e violência física e simbólica foram expedientes utilizados por todas as modalidades de piquete descritas a seguir, as quais coexistiram em diversos momentos da greve, variando, em boa medida, a importância relativa de cada uma delas em função da intensidade e formas de repressão adotadas pelo Estado para confrontar a mobilização operária. ${ }^{36}$

Os "piquetes em porta de fábrica" eram, em grande medida, preparados a partir do sindicato e contavam, fundamentalmente, com ativistas sindicais - muitos deles militantes de organizaçôes políticas de esquerda que já atuavam clandestinamente no espaço fabril —, podendo reunir até centenas de participantes. ${ }^{37}$

Por sua visibilidade pública, esta modalidade de piquete era uma das mais visadas pela polícia. Características que também atraíam, não poucas vezes, importantes figuras públicas, em especial parlamentares, que, juntando-se aos trabalhadores, atuavam no sentido de mediar conflitos e oferecer limites à violência policial. Nos primeiros dias da greve de 1980, essa forma de piquete pouco atuou. O próprio sindicato a desestimulou visto que, há poucos meses, um importante líder metalúrgico na cidade de São Paulo, Santos Dias, havia sido assassinado pela polícia em um piquete desse tipo. Entretanto, conforme a paralisaçáo se estendia, aumentava importância do "piquete em porta de fábrica" uma vez que alguns operários tentavam retornar ao trabalho. ${ }^{38}$

\footnotetext{
${ }^{35}$ Cf. SADER, Eder. Quando novos personagens entraram em cena: experiências, falas e lutas dos trabalhadores da Grande São Paulo (1970-80). Rio de Janeiro: Paz e Terra, 1988 e MENEGUELLO, Rachel. PT: a formação de um partido (1979-1982). Rio de Janeiro: Paz e Terra, 1989.

${ }^{36}$ Uma fonte impressionante para observar a ação dos piquetes na greve de 1980 são os vários filmes realizados durante os movimentos dos metalúrgicos em 1979 e 1980. Neles os piquetes foram recorrentemente filmados. Ver, por exemplo, os filmes Greve! Direção: João Batista de Andrade. Brasil, 1979. Vídeo. (37 minutos); $A B C$ da greve. Direção: Leon Hirszman. Brasil, 1979. DVD. (75 minutos); Linha de montagem. Direção: Renato Tapajós. Brasil, 1982. DVD. (90 minutos). Segundo Silva (2008), as greves dos metalúrgicos do ABC foram as mobilizaçôes operárias mais abordadas por cineastas na história brasileira.

${ }^{37}$ Cf. Relatório n. 035/80. OS - 1147. Aesp, setor Deops.

${ }^{38}$ Cf. A Vanguarda, 5/4/1980.
} 
Com o julgamento da ilegalidade da greve pelo Tribunal Regional do Trabalho, em 14 de abril, e a decretação da intervenção federal no sindicato, essa modalidade de piquete sofreu sérias restriçôes em função do aumento do contingente policial que passou a "acampar" em São Bernardo do Campo, ${ }^{39}$ sobretudo nas áreas centrais e em portas de fábricas. Nesse momento, os "piquetes em bairros" — que já vinham ocorrendo fundamentalmente nos pontos de ônibus - cresceram em importância. Eram, em geral, agrupamentos menores que os "piquetes em porta de fábrica" e contavam bastante, em sua constituição, com ativistas sindicais, os quais, entretanto, mobilizavam suas redes sociais nos bairros em que residiam, incorporando colegas de trabalho, vizinhos, amigos, parentes etc. aos piquetes. ${ }^{40}$

A partir do dia 19 de abril, com o início das prisóes de diretores e ativistas sindicais, a proibição das assembleias gerais em espaços públicos e o sitiamento do $\mathrm{ABC}$ paulista pelas forças de repressão do Estado, os bairros tornaram-se crescentemente o espaço fundamental da mobilização coletiva. ${ }^{41}$ Nessas circunstâncias, várias modalidades informais de "agrupamentos de coaçáo" ampliaram sua importância na mobilização operária, podendo contar com um número extremamente variável de participantes, entre estes havendo ativistas sindicais ou não. Como chegaram a coagir fura-greves em suas próprias residências, chamemos tais agrupamentos de "piquetes em porta de casa".

Uma análise cuidadosa da documentação policial relativa às prisóes de trabalhadores acusados de atuar em piquetes nos revela que a constituição dos mesmos mobilizou um amplo leque de lealdades preexistentes baseadas em parentesco, amizade, vizinhança e conterraneidade. Vigorosos indícios da relevância que determinadas inserçóes em redes sociais poderiam ter para o engajamento em piquetes e confrontos com a polícia são as prisóes de trabalhadores que, possuindo vínculos com algum grevista, envolveram-se em tais açóes, mesmo não sendo metalúrgicos. ${ }^{42}$

Sugerindo-nos a existência de um denso tecido relacional nos bairros em que os trabalhadores residiam, é possível afirmar que tais vínculos tiveram presença mais marcante nos piquetes constituídos para atuar "em porta de casa" e "em bairro". Isso não significa, contudo, que tais vínculos estivessem ausentes nos "piquetes em porta de fábrica”. É claro que muitos trabalhadores, independentemente de tais laços com outros piqueteiros, engajaram-se em piquetes, seja por ativismo sindical, pertencimento a organizaçóes partidárias (ou de outro tipo) ou, simplesmente, por entenderem que as reivindicaçôes da greve eram justas e quererem levá-las adiante. Nesse sentido, a diretoria do sindicato, a comissão de salários,

${ }^{39}$ Cf. DGABC, 19/4/1980. As forças de segurança do Estado envolvidas diretamente na repressão à parede foram: Polícia Militar, Deops, Polícia Federal, Polícia Civil, Corpo de Bombeiros e Exército.

${ }^{40}$ Entrevista com José, concedida a Martins, Pereira e Ricardo, 1980, p. 38.

${ }^{41}$ Cf. 41 Dias de Resistência e Luta. Cadernos do Trabalhador 1. São Bernardo: ABCD Sociedade Cultural, 1980, p. 27. Esta obra, tentando sintetizar avaliaçóes sobre a mobilização coletiva findada em 11 de maio de 1980, foi publicada após uma série de debates, em julho de 1980, com cinquenta ativistas "que tiveram atuação destacada durante a greve".

${ }^{42}$ Para um episódio significativo, cf. Prontuário 149.689 (v. 1). 
as reuniôes em igrejas e sociedades amigos de bairros, bem como as próprias assembleias públicas, foram instâncias articuladoras que puseram em contato e coordenaram muitos operários que empreenderam piquetes em suas diversas modalidades. Até mesmo um piquete que atuaria "em porta de casa" poderia passar pelas mencionadas instâncias. ${ }^{43}$ No que tange à constituição de piquetes "em porta de fábrica" ou "em bairro", o papel da diretoria do sindicato e da comissão de salários foi ainda mais decisivo. ${ }^{44}$ Mesmo os piquetes que se constituíam a partir de vínculos informais preexistentes e das lealdades nestes presentes interagiam com demandas e orientaçôes da diretoria do sindicato, da comissão de salários e das assembleias gerais públicas. Assim, ainda que possam estar ancoradas em tais laços, as açóes dos piquetes adquiriam um sentido contextual baseado na conjuntura política e em valores morais vigentes entre os trabalhadores.

Com efeito, racionalidade politica e moralidade estiveram - em geral, simultaneamente - presentes na orientaçáo da atuaçáo dos piquetes ao longo de toda a parede metalúrgica. Entretanto, é possível delinearmos dois momentos, sendo que, no primeiro, preponderou a racionalidade política e, no seguinte, a moralidade. Preponderâncias que, por sua vez, estiveram associadas a importantes mutaçôes nos "sentidos da violência" ${ }^{45}$ empregada pelos piquetes.

Entre $1^{\circ}$ e 30 de abril, quando a ação dos piquetes foi preponderantemente orientada por racionalidade política, eles fizeram, de modo geral, uso moderado de violência, inclusive física, com o objetivo fundamental de agregar os operários - obtendo adesão ou permanência em greve - em torno do movimento paredista. Pautados por um sentido de intervenção política em momentos críticos do confronto com patrôes e Estado, os piquetes almejavam, basicamente, contrabalançar os constrangimentos impostos por ambos os antagonistas, buscando estabelecer um equilíbrio das pressóes que atuavam sobre os operários metalúrgicos em sua tomada de decisóes sobre a parede. Dessa forma, como a greve de 1980 ainda era um evento "em aberto" e fura-greves poderiam converter-se em grevistas (e vice-versa), raramente piqueteiros fizeram, nos primeiros 30 dias da parede, uso desmedido de violência. Nesse período, convencimento argumentativo e coação moral tinham amplo espaço na ação dos piquetes, os quais, buscando, fundamentalmente, intimidar fura-greves e grevistas vacilantes recorriam, também em larga escala, a ameaças verbais e múltiplas formas de violência simbólica e física. O uso moderado de violência colaborava, adicionalmente, para evitar epi-

\footnotetext{
${ }^{43}$ Cf. Auto de prisão em flagrante delito de João S. L. M. e de Leonardo R. C. Del. Pol. de São Bernardo do Campo. 5/5/1980. OS - 0096.

${ }^{44}$ Cf. Entrevista com Djalma Bom, concedida a Francisco Macedo em 24/10/2008 e 31/10/2008.

${ }^{45}$ A abordagem aqui sugerida para uso de violência pelos piquetes pouco tem de original. Desde os anos 1960, pesquisas de história social, principalmente nos Estados Unidos e na Europa, insistem no "caráter racional e instrumental" que o uso de violência pode assumir em açôes coletivas. A relação entre moralidade e violência, por sua vez, remete-nos ao "vínculo entre cultura e violência", o qual é considerado pelas ciências sociais desde a primeira metade do século XX. Cf. WIERVIORKA, Michel. Violência hoje. Ciência \& Saúde Coletiva, Rio de Janeiro, v. 11, 2007.
} 
sódios que pudessem repercutir negativamente junto ao "olhar público" que acompanhava a parede metalúrgica.

Contudo, após 30 de abril e, em especial, entre 4 e 10 de maio, última semana da greve, quando a moralidade predominou na orientação dos piquetes, as conotaçôes punitivas vão se sobressair na ação dos mesmos, sendo mais frequente o uso imoderado de violência - física, em especial, que fica sugerido pelo aumento dos espancamentos de fura-greves e de apedrejamentos sumários de ônibus que os conduziam aos locais de trabalho. ${ }^{46}$ As múltiplas modalidades de violência, que haviam sido prioritariamente empregadas com um sentido agregador, passaram, então, a servir, predominantemente, como práticas confirmadoras da exclusão dos fura-greves da "comunidade moral" dos grevistas. Esta, na medida em que a "Greve dos 41 dias" perdia seu caráter de evento "em aberto", "fechava-se", uma vez que, virtualmente, a parede metalúrgica já não mais existia como evento para que dele se participasse. De fato, a partir de 30 de abril, muitos operários, pressionados pelas ameaças patronais, pela intensa repressão policial, pela falta de perspectivas políticas para o movimento e pelas inúmeras dificuldades econômicas experimentadas pelos grevistas devido ao longo período de paralisação, buscaram retornar ao trabalho. Ainda que a greve de 1980 estivesse praticamente selada como evento político, piqueteiros continuaram agindo. Se, no que tange à racionalidade política, os piquetes mostravam-se cada vez mais desprovidos de sentido, do ponto de vista da moralidade, os fura-greves — inúmeras vezes chamados de "sem-vergonhas" e "traidores" - mereciam, para muitos piqueteiros e operários engajados na parede, ser punidos, o que fundamentava a ação dos piquetes, expressando assim a própria configuração da "greve dos 41 dias" como, simultaneamente, "comunidade de interesses" e "comunidade de valores".

\section{Conclusôes}

O estudo comparativo da constituição e atuação dos piquetes nas greves de 1957 e 1980 sugere-nos que, talvez, eles devam ser investigados como parte proeminente de um repertório de açáo coletivado operariado da Grande Sáo Paulo na segunda metade do século XX, indicando-nos importantes elementos de continuidade no processo de formaçâo de classe em curso. ${ }^{47}$

Neste período de notável expansão da base industrial do país e de concentração de trabalhadores em grandes fábricas e em áreas metropolitanas, conexôes entre fábricas e bairros estiveram presentes em outras diversas açóes coletivas do operariado da regiáo metropolitana

\footnotetext{
${ }^{46}$ Segundo os boletins de ocorrência lavrados pela Chefia de Segurança Industrial da Volkswagen, até 30 de abril, três ônibus teriam sido apedrejados. Entre 2 e 8 de maio, por sua vez, o número subiu para 29. Cf. BOs emitidos pela Chefia de Segurança Industrial da Volkswagen. OS - 1148

${ }^{47}$ TILLY, Charles. Contentious Repertories in Great Britain, 1758-1834. Social Science History, Londres, v. 17, n. 2, 1993.
} 
de São Paulo. A Greve dos 300 Mil (1953), por exemplo, que envolveu várias categorias de trabalhadores paulistanos, já havia revelado "a existência de uma cultura criada nas fábricas e nos bairros capaz de sustentar as grandes lutas necessárias para a defesa dos trabalhadores”. ${ }^{48}$ Similarmente, quando, a partir de fins dos anos 1970, centenas de milhares de trabalhadores fomentaram a onda grevista que se espraiou pela região metropolitana de São Paulo, foi possível, com frequência, notar uma "adaptação de redes de organizaçôes sociais interpessoais, tais como as associaçóes de bairro, os clubes esportivos, ou grupos religiosos, para auxiliar na mobilização dos trabalhadores". ${ }^{4}$

A análise dos piquetes nas greves de 1957 e 1980 reitera tais observaçóes sobre a articulaçáo de múltiplas experiências e espaços sociais. Se vivências nos locais de trabalho e a percepção da exploraçáo fabril fomentavam as principais demandas dos trabalhadores, estimulando-os às greves, vínculos tecidos nos locais de moradia e em outros espaços de sociabilidade ofereciam evidente substrato para o empreendimento das mobilizações coletivas, o que deve chamar nossa atenção para os variados e recorrentes modos pelos quais, nesse período, os trabalhadores brasileiros atuaram sob(re) os processos de industrialização, migração, urbanização, articulando-os, muitas vezes, por meio de suas redes sociais. ${ }^{50}$

Além disso, contrariando imagens contemporâneas que teimam em perpetuar a ideia dos piquetes como modalidade de ação coletiva agressiva e desorganizada, beirando a irracionalidade, ${ }^{51}$ as evidências sobre os piquetes nas greves de 1957 e 1980 apontam-nos como configuraçôes sociais altamente estruturadas e complexas - pautadas simultaneamente por interesses e valores/racionalidade política e moralidade — que se valiam de diversas formas de violência sob regras e contextos bastante compreensíveis. Os usos e sentidos com que diversas modalidades de violência têm sido empregadas em piquetes parecem-nos, portanto, mais um elemento de continuidade de um repertório de açâo coletiva partilhado pelos trabalhadores da Grande São Paulo na segunda metade do século XX.

Finalmente, os piquetes foram uma das principais maneiras pelas quais os trabalhadores se expressaram publicamente, adquirindo uma visibilidade — para si e para os outros — que

\footnotetext{
${ }^{48}$ HALL, Michael. O movimento operário na cidade de São Paulo: 1890-1954. In: PORTA, Paula (Org.). História da Cidade de São Paulo. Sáo Paulo: Paz e Terra, 2004, p. 289. v. 3.

${ }^{4}$ SANDOVAL, Salvador. Os trabalhadores param. Greves e mudanças sociais no Brasil, 1945-1990. São Paulo, Ática, 1994, p. 211.

${ }^{50}$ Para um balanço bibliográfico dos debates sobre a importância de vínculos interpessoais em mobilizaçōes coletivas, cf. KITTS, J. Mobilizing in black boxes: social networks and participation in social movements organizations. Mobilization: An International Journal, v. 5, n. 2, 2000. Para duas seminais investigaçóes sobre o tema cf. McADAM, Douglas. Recruitment to High-risk Activism: the Case of Freedom Summer. American Journal of Sociology, v. 92, n. 1, 1986 e GOULD, Roger. Insurgent Identities: Class, Community and Protest in Paris from 1848 to the Commune. Chicago: University of Chicago Press, 1995.

${ }^{51}$ Neste sentido, ver a interessante análise sobre as imagens dos piquetes no filme Lula, filho do Brasil. Direção: Fábio Barreto, 2009. DVD. (128 minutos) em FRENCH, John e NEGRO, Antonio Luigi. Politics, Memory, and Working Class Life in the Commercial Biopic Lula, Son of Brazil. A contra corriente, v. 8, n. 3, 2011.
} 
lhes era cerceada ou completamente negada em diversas conjunturas políticas. Tendo que atuar politicamente diante de um aparato estatal que, mesmo em períodos democráticos, mantinha a classe trabalhadora e suas organizaçôes sob vigilância policial, os trabalhadores recorrentemente viram nos piquetes uma maneira de se manter ou conquistar o espaço público com alguma segurança, protegendo-se de represálias da polícia e dos patróes. Eficientes instrumentos de comunicação e organização, os piquetes fomentaram a coesão dos trabalhadores, abrindo espaço para seu engajamento em massivas mobilizaçóes coletivas. Além disso, por seu caráter público, os piquetes frequentemente agregavam o apoio e, até mesmo, a presença de outros setores sociais que se sentiam contemplados nas demandas dos trabalhadores.

\section{Referências bibliográficas}

ALVES, Maria Helena Moreira. Estado e oposição no Brasil (1964-1984). Petrópolis: Vozes, 1984.

ANTUNES, Ricardo. As formas da greve: o confronto operário no ABC paulista (1978-1980). São Paulo. Tese (Doutorado) — FFLCH-USP, 1986.

COLISTETE, Renato. Labour Relations and Industrial Performance in Brazil. Greater São Paulo, 1945-60. Houndmills: Palgrave, 2001.

CORRÊA, Larissa Rosa. A tessitura dos direitos. Patrôes e empregados na Justiça do trabalho, 1953-1964. São Paulo: LTR, 2011.

COSTA, Hélio. Em busca da memória. Comissão de fábrica, partido e sindicato no pósguerra. São Paulo: Scritta, 1985.

FONTES, Paulo. Trabalhadores e cidadãos. Nitro Química: a fábrica e as lutas operárias nos anos 50. São Paulo: Annablume, 1997.

. The strike of 400,000 and the workers' organization in São Paulo, Brazil, 1957. Socialist History Journal, Londres, v. 17, p. 61-75, 2000.

FORTES, Alexandre et al. Na luta por direitos. Estudos recentes em história social do trabalho. Campinas: Editora da Unicamp, 1999.

FRENCH, John; NEGRO, Antonio Luigi. Politics, Memory, and Working Class Life in the Commercial Biopic Lula, Son of Brazil. A contra corriente, v. 8, n. 3, 2011.

GOULD, Roger. Insurgent identities: class, community and protest in Paris from 1848 to the Commune. Chicago: University of Chicago Press, 1995.

HALL, Michael. O movimento operário na cidade de São Paulo: 1890-1954. In: PORTA, Paula (Org.). História da Cidade de São Paulo. São Paulo: Paz e Terra, 2004. v. 3. 
HUMPHREY, John. Fazendo o "milagre": controle capitalista e luta operária na industria automobilistica brasileira. Petrópolis: Vozes, 1982.

KITTS, J. Mobilizing in black boxes: social networks and participation in social movements organizations. Mobilization: An International Journal, v. 5, n. 2, 2000.

KOWARICK, Lucio (Org.). As lutas sociais e a cidade. São Paulo: passado e presente. Rio de Janeiro: Paz e Terra, 1988.

LEITE, Márcia de Paula Leite. Trabalhadores, sindicatos e partidos: a greve de 1957 em São Paulo. In: . El sindicalismo latino americano em los ochenta. Santiago del Chile: Clasco, 1985.

LOPES, Juarez Brandão. O ajustamento do trabalhador à indústria: mobilidade social e motivação. In: HUTCHINSON, Bertram. Mobilidade e trabalho: um estudo na cidade de São Paulo. Rio de Janeiro: Centro Brasileiro de Pesquisas Educacionais, 1960.

LOPES, Nádia Aparecida Lopes de Camargo. A geografia das lutas metalúrgicas no ABC paulista na virada dos anos 70 do século XX. São Paulo, Dissertação (Mestrado) - FFLCHUSP, 2003.

MACEDO, Francisco Barbosa. A greve de 1980: redes sociais e espaço urbano na mobilização coletiva dos metalúrgicos de Sáo Bernardo do Campo. Mundos do Trabalho, Florianópolis, v. 3, n. 5, p. 136-165, jan./jun. 2011.

MARONI, Amneris. A estratégia da recusa: análise das greves de maio/78. São Paulo: Brasiliense, 1982.

MARTINS, Heloísa de Souza; PEREIRA, Hamilton; ANTUNES, Carlos Alberto. A Igreja na greve dos metalúrgicos - São Bernardo, 1980. Religião e Sociedade, São Paulo, v. 6, novembro 1980.

MARTINS, José de Souza. Uma arqueologia da memória social. Autobiografia de um moleque de fábrica. São Paulo: Ateliê Editorial, 2011.

MATTOS, Marcelo Badaró. Novos e velhos sindicalismos. Rio de Janeiro (1955-1988). Rio de Janeiro: Vício de Leitura, 1998.

McADAM, Douglas. Recruitment to High-risk Activism: the Case of Freedom Summer. American Journal of Sociology, v. 92, n. 1, 1986.

MENEGUELLO, Rachel. PT: a formaçáo de um partido (1979-1982). Rio de Janeiro: Paz e Terra, 1989.

MOISÉS, José Álvaro. Greve de massa e crise política (estudo da Greve dos 300 mil em São Paulo, 1953-54). São Paulo: Polis, 1978.

. Liçóes de liberdade e de opressão: os trabalhadores e a luta pela democracia. Rio de Janeiro: Paz e Terra, 1982.

MUNHOZ, Fabio. Sindicalismo e democracia populista: a greve de 1957. São Paulo: Cedec, 1977. 
NEGRO, Antonio Luigi. Linhas de montagem. O industrialismo nacional-desenvolvimentista e a sindicalização dos trabalhadores. São Paulo: Boitempo, 2004.

NETO, Murilo Leal Pereira. A reinvenção da classe trabalhadora (1953-1964). Campinas: Editora da Unicamp, 2011.

NORONHA, Eduardo. Ciclo de greves, transição política e estabilização: Brasil, 19782007. Lua Nova, São Paulo, v. 76, p. 119-168, 2009.

SANTANA, Marco Aurélio. Homens partidos: comunistas e sindicatos no Brasil. São Paulo: Boitempo, 2001.

SANDOVAL, Salvador. Os trabalhadores param. Greves e mudanças sociais no Brasil, 19451990. São Paulo: Ática, 1994.

RAINHO, Luis Flávio. Os peóes do grande ABC. Petrópolis: Vozes, 1980.

; BARGAS, Osvaldo. As lutas operárias e sindicais dos metalúrgicos em São Bernardo (1977-1979). São Bernardo do Campo: ABCMSBCD, 1983. v. 1.

RODRIGUES, Leôncio Martins. Conflito industrial e sindicalismo no Brasil. São Paulo: Difel, 1966.

SADER, Eder. Quando novos personagens entraram em cena: experiências, falas e lutas dos trabalhadores da Grande São Paulo (1970-80). Rio de Janeiro: Paz e Terra, 1988.

SILVA, Maria Carolina Granato. O cinema na greve e a greve no cinema. Tese (Doutorado) — UFF, Niterói, 2008.

TILLY, Charles. Contentious Repertories in Great Britain, 1758-1834. Social Science History, Londres, v. 17, n. 2, 1993.

WEINSTEIN, Barbara. (Re) formação da classe trabalhadora no Brasil (1920-1964). São Paulo: Cortez, 2000.

WIERVIORKA, Michel. Violência hoje. Ciência \& Saúde Coletiva, Rio de Janeiro, v. 11, 2007.

WOLFE, Joel. Working women, working men - São Paulo and the rise of Brazil's industrial working class, 1900-1955. Durham: Duke University Press, 1993. 